\title{
Antiglobalization and Radical Environmentalism: An Exchange on Ethical Grounds
}

Paul Joosse (University of Alberta; Edmonton, Alberta, Canada)

\section{Introduction ${ }^{1}$}

Today, a sense of futility pervades many environmentalists' attitudes toward traditional channels of political influence. The Bush administration's rejection of the Kyoto protocol and the utter lack of political will displayed at the Copenhagen Climate Summit have been major defeats for conventional moderate lobby groups and environmentally-conscious political parties. The economic crisis of late 2008 and the subsequent recession became an occasion for a further marginalization of environmentalism in the corridors of power, evidenced recently when, with jobs being the forefront issue, both Barack Obama and Mitt Romney competed to boast about their credentials as friends of coal (NPR 2012; Vozzella 2012). As the political currency of environmentalism has declined in value, corporate interests have seemed only to get stronger, pushing to commodify ever more areas of public life (Soron and Laxer 2006). Indeed, the advancement of corporate power has reached new levels of insidiousness, with the advent of "greenwashing" (Vos 2009), "aggressive mimicry" (Peeples 2005), and the "linguistic high-jacking" of concepts such as sustainability (Johnston 2004, 1) -cynical appropriations of the stylings of environmentalism itself. For environmentalists who take the apocalyptic visions of ecological and climatological science seriously, these have no doubt been bitter developments.

Thus, while there have been surges in popular enthusiasm for environmental causes in the past-of which the success of Al Gore's An Inconvenient Truth is only the most prominent example-many who have held long-standing commitments to the movement see these developments as hollow and insubstantial. Indeed, such enthusiasms, which often manifest as calls for

\footnotetext{
1 Thanks must go to the guest editors and anonymous reviewers at Ethics in Progress Quarterly for their valuable comments on this manuscript. I am also grateful to Stephen Kent for his invaluable guidance throughout my writing, and for granting me access to the Kent Collection on Alternative Religions, housed at the University of Alberta. Support for this research was provided by the Social Sciences and Humanities Research Council (SSHRC) and by the University of Alberta PhD Dissertation Fellowship.
} 
technological solutions to environmental ills, nearly always obfuscate what is seen as the most important factor contributing to environmental decline: global capitalism's inherent pursuit of unfettered economic growth. Habermas (1981) was right to characterize (traditional) environmentalism as a "defensive" social movement because of its heritage of resistance to this expansionistic tendency. Indeed, its historical mandate has been to defend against the erosion of the lifeworld by the ever-increasing complexity of the economic-administrative complex, and in this vein, one of its essential qualities is a strident "critique of growth" (Habermas 1981, 34). Thus, many see calls for "ecological modernization," "sustainable development," and "wise use," as betrayals of environmentalism's true character. Representing this attitude in paradigmatic fashion is Richard Smith, who laments:

As long as [Tony] Blair, [Sir Nicholas] Stern, Al Gore, and the rest of the corporate and political elite are committed to maintaining and perpetuating global capitalism as their first and foremost priority, they have no choice but to subordinate the environment to growth and consumption, override their own environmental targets, turn themselves into hypocrites, and doom the future of humanity $(2007,26)$.

Accordingly, for many, the present era of carbon credits, "clean coal," and slick "corporate responsibility" campaigns promises nothing more than a continuance of environmental depletion on a global scale. Environmental ethics in this climate are thus an ethics in progress-a desperate striving for novel answers to that fundamental question, 'what is to be done?'

Increasingly, some are answering this question by taking up arms. Existing on the "radical cusp" between political action and militancy (Beck 2007) is the Earth Liberation Front (ELF) which, since 1997, has committed over 600 acts of sabotage and arson in North America, causing over $\$ 100$ million in damages to biomedical research centres, logging companies, ski resorts, and SUV dealerships (Joosse 2012; Rosebraugh 2004). Abandoning traditional politics in favor of "direct action," this group and others like it seek to create a transnational, revolutionary challenge to neoliberal globalism.

New avenues for ethical consideration and critique are inevitably raised by these developments, and this article will serve as a vehicle for a preliminary airing of some of these. Specifically, in what follows I make the case that the rise of radical environmentalism in North America is part and parcel of the larger development of the more general anti-globalization/anti-capitalist movement, a fact that allows for a 'cross-pollination' of critique between the two phenomena. Ethical debates that take place within the antiglobalization movement can have salience when considering radical environmentalism-and vice versa. Following from this premise, I assess the applicability of three major criticisms of "globalization from below" (described below) to the case of the ELF, namely: a) that its preoccupation with the transnational sphere and 
abandonment of national electoral politics is misguided; b) that direct actions such as property destruction are counterproductive to the wider aims of the movement; and c) that episodic cycles of contention, whether they be in the form of mega-protests or direct action attacks do very little to encourage practical, local, and sustained action in the service of global justice.

Thus, while others have sought to assess whether the actions of the ELF can be justified morally on its own terms (Vanderheiden 2005; Brown 2007), this article seeks to situate radical environmentalism in a wider context of political contention, assessing the ethical and tactical feasibility ELF-style direct action. In his rebuttal against those who would equate ecotage/monkeywrenching2 with terrorism, Vanderheiden writes: "Defending ecotage as distinct from terrorism need not necessarily entail endorsing it as an effective part of a larger strategy, and more debate over its merits and perils is needed before the former can be taken to involve the latter" (Vanderheiden 2008, 316).

I hope that this paper will contribute to the discussion by positioning debates over ecotage and environmentally-motivated arson within the larger discourses and ethical considerations of the anti-globalization movement.

\section{The Anti-Globalization Movement}

Variously called anti-capitalism (McNally 2002), "globalization from below" (Falk 1993; della Porta 2005; della Porta 2006), or "alter-globalization" (Best and Nocella 2006c, 20; Starr 2006), the anti-globalization movement seeks to tie together a wide range of issues into a global "movement of movements" (Harvie, Milburn, Trott and Watts 2005), which accommodates a slew of different and sometimes conflicting struggles surrounding issues such as global warming, human rights, nuclear proliferation, and poverty. If there is one unifying theme for the movement, however, it seems to be an agreement on the need to challenge the neoliberal domination of the transnational sphere, what Richard Falk refers to as "globalization-from-above" $(1993,39)$.

Though the movement has had a long developmental history, with precedents going back to the anti-slavery and international workers movements during the era of European colonialism (Broad and Heckscher 2003), its modern formulation is widely seen to have come to a head through a series of mega-protests at major meetings of the G8, World Bank, IMF, Summit of the Americas, and WTO. Also important have been venues such as the World

\footnotetext{
${ }^{2}$ Earth First! leader Dave Foreman defined monkeywrenching as "nonviolent resistance to the destruction of natural diversity and wilderness. It is never directed against human beings or other forms of life. It is aimed at inanimate machines and tools that are destroying life. Care is always taken to minimize any possible threat to people, including to the monkeywrenchers themselves" (Foreman and Haywood 1993, 9).
} 
Social Forum, which have explored the possibility of a "new kind of globalization" (Ramonet 2001). The movement had gathered so much momentum by the turn of the century that Walden Bello went so far as to predict that the year 2000 (in which he includes November 1999's "Battle of Seattle") "would go down as one of those defining moments in the history of the world economy, like 1929” (Bello 2001, 1).

Despite sporadic resurgences (the Occupy movements being the most recent iteration [Gitlin 2012]), the revolutionary acceleration that Bello saw in 2001 seems to have stalled. According to Gregory Albo, a change in the "ideological climate" since the attacks of September 11, 2001, has "sealed the political opening that was being exploited by the anti-globalization movement" and has "provide[d] a serious check on the freedom of assembly" (quoted in French 2002, 3). Indeed, in the wake of the attacks on the World Trade Center and the Pentagon, we have seen a delegitimation of protest tactics generallyespecially those that would directly and fervently challenge basic principles of liberal democracies. The implementation of the PATRIOT Act has undoubtedly served to stymie radical mobilizations in the US, both through the creation of legal climes that are favorable to the counter-mobilizations of state agencies such as the FBI, and, more generally, through the fear that it inspires in potential anti-globalization movement adherents.

Aside from these external factors, the tactics of the anti-globalization movement have met with considerable controversy even among those who are generally ideologically sympathetic. For instance, some on the left are strongly critical, claiming that the movement as it has manifested contains many strategic deficiencies. Below, I will describe these general criticisms of antiglobalization and determine whether they are applicable to the specific case of the ELF. First, however, I must make the case that it makes sense to regard the ELF and its actions as being part of, or at least analogous to, the antiglobalization movement.

\section{The Historical Rise of Anarchism and Anti-Globalist Sentiments in the Radical Environmental Movement}

Although direct action among workers' movements has a history that stretches back to the Luddites of 19th century England, direct actions motivated by "deep ecological”3 environmental concerns first appeared only twenty-five years ago.

${ }^{3}$ In 1973, Norwegian philosopher Arne Naess made a distinction between the 'deep' and 'shallow' ecological movements. The main difference that he saw between these movements is that deep ecology is biocentric, while shallow ecology is anthropocentric. In other words, deep ecology sees things in nature as having intrinsic worth, while shallow ecology sees nature as having only instrumental value in that it serves humanity's wants and needs (Naess 1973). 
At this time, radical environmentalist groups like Earth First! began employing direct action tactics such as civil disobedience and monkeywrenching in their efforts to halt the degradation of wilderness. Before 1992, when Earth First! abandoned its sanctioning of illegal tactics (Taylor 1998, 20; see also Molland 2006, 48-51), treespiking, treesitting, and the sabotage of logging equipment were hallmarks of the movement.

This development owes to a particular set of historical circumstances that favored unconventional protest and action through two motivational factors. First, the advent of Ronald Reagan's presidency 1981 fostered a general fear about his environmentally irresponsible vision for America. This was especially so during the tenure of Reagan's first Secretary of the Interior, James Watt, who many saw as representing the most irresponsible form of Christian millenarianism. ${ }^{4}$ Rothman maintained that, at this time, "mainstream environmental organizations experienced remarkable growth in membership as a direct result of Watt's policies" $(2000,170)$. It would seem, however, that radical groups experienced this growth as well. Prominent Earth First!er Christopher Manes also saw an "influx of people frightened into environmental activism by the retrograde policies of President Reagan's maladroit and messianic secretary of the interior, James Watt" $(1990,49)$.

Despite the current liberal or anarchical reputation of the radical environmental movement, it is important to note that at this stage in its development, Earth First! bore the indelible stamp of its most important forbearer, Edward Abbey. ${ }^{5}$ Indeed, it initially attracted mainly those with libertarian tendencies or, as Foreman's supporters playfully referred to themselves - "rednecks for wilderness" (Taylor 2005, 519). Thus, Foreman, a supporter of the Vietnam War and former campaign manager for Barry Goldwater (Lee 1995, 27), does not at all typify the group that Earth First! eventually became, nor the splinter group that would lead to the ELF. Writes Taylor:

Foreman wished to focus the movement exclusively on conserving the earth's biological diversity ... . He did not assume that nation-states were intractably corrupt and impossible to influence democratically. Unlike a growing number of Earth First!ers, Foreman did not consider himself a revolutionary at

\footnotetext{
${ }^{4}$ It was widely reported that, in Congress, Watt once refuted arguments for conserving natural resources by saying, "I do not know how many future generations we can count on before the Lord returns" (Martin 1982, 35).

5 Edward Abbey was an American novelist, essayist, and raucously libertarian conservative who wrote The Monkey Wrench Gang, a novel about a troupe of ecobandits who seek to preserve the American southwest from development through the sabotage of machinery such as bulldozers and trains. The book was a major source of inspiration for Dave Foreman and other founders of Earth First!, and the term 'monkeywrenching' (see note 2) entered the radical environmental vernacular through the book's popularity.
} 
war with the entire industrial system or western civilization itself $(2005,519)$.

Indeed, as the 1980s progressed, Foreman began to lament the anarchical direction that the movement was taking, and he found it increasingly necessary to point out to newer members that Earth First! did "not emerge from the anarchist movement, or from the left. Neither were we born of sea foam, like The Birth of Venus. Earth First! came directly out of the public lands conservation movement" (Foreman 1991, 217). He resented those who "wear their 'radicalness' as a badge ... [and who] have been attracted to Earth First! because it represented to them a reincarnation of the style and intensity of the New Left" (Foreman 1991, 217). In Taylor's analysis, Foreman led a disgruntled faction of old guard Earth First!ers who believed "that tying environmental protection to other issues, such as social justice, antiimperialism, or workers' rights, alienates many potential wilderness sympathizers"-Earth First!'s traditional base $(1994,199)$. In 1989, when it became clear to Foreman that the anarchical turn within Earth First! would be lasting, he left altogether and started the Wildlands Project and its affiliated journal, Wild Earth. ${ }^{6}$

If traditional Earth First! members such as Dave Foreman were leaving because of ideological disagreements, others, who had no qualms with the anarchical turn, were growing disgruntled with the organization's movement towards abandoning illegal tactics (Taylor 1998, 20; see also Molland 2006, 4851). These newer members would not truck with the leadership's attempts to quell monkeywrenching and other more extreme forms of direct action. Although it is difficult to pinpoint with certainty the moment that clandestine groups like the ELF form, Taylor cites various Earth First! sources which claim that the ELF began as a radical offshoot of Earth First! in England in 1992 $(2005,521)$. Plows, Wall, and Doherty (2004) interviewed members of Britain's Earth First!, and among them was Edgar (pseudonym) who recalls that at Earth First!'s national gathering of that year it was agreed that:

Earth First! would be split into two. On the one hand there would be an underground group the Earth Liberation Front which would do ecotage and all the embarrassing naughtiness stuff and, on the other hand, all the open civil disobedience kind of thing that would retain the name Earth First! ... people were insisting there if there was going to be a split it shouldn't be a case of competition between units. They should be supportive so there should be toleration by groups (Plows et al. 2004, 202).

Despite the apparent amiability of this schism as Edgar describes it, Plows et al. go on to note that "most in EF! (UK) were hostile to the ELF, viewing it as a

${ }^{6}$ Wild Earth ceased publication in 2004. 
product of masculine posturing" (2004, 202). This first British wave of attacks seems to have inspired similar developments in North America. By 1996, ELF actions were occurring in the United States, and have continued at a remarkable pace ever since then (Molland 2006, 53-55). James Jarboe, the FBI's top domestic terrorism officer, linked the ELF to 600 criminal acts committed between 1996 and 2002, totaling \$43 million in damages (Leader and Probst 2003, 38). Most destructive of these was the arson of Vail Ski Resort in Colorado resulting in $\$ 12$ million in damages. In August 2003, the ELF claimed responsibility for the arson of a 206-unit apartment complex that had been under construction in San Diego, causing roughly $\$ 50$ million in damages (Ackerman 2003a, 143). In March of 2008, north of Woodinville, Washington, four yet-to-be-inhabited multimillion dollar homes that had been advertised as 'eco-friendly' were burned. The banner allegedly left by ELF adherents read, "Built green? Nope black! McMansions in RCD's [rural cluster developments] r [are] not green. ELF."

There are three reasons why it no longer makes sense to postulate a necessary connection between Earth First! in the USA and what is now known as ELF. First, similar to the British context, though the initial call for the development of the ELF came from within Earth First!'s ranks, there are undoubtedly many in Earth First! who are unsupportive and even hostile to the ELF because of its tactics. Second, with the rhizomatic branching that characterizes the way that the ELF garners recruits (Joosse 2007), the ELF has outgrown any necessary ties with its parent organization as a simple matter of organizational drift. Finally, the notoriety of the ELF, because of their penchant for arson attacks, has reached a scale that far surpasses any achieved by Earth First! in the past (Joosse 2012).

\section{The Anti-Globalist ELF Ideology}

In the pamphlet "Frequently Asked Questions" published by the North American ELF Press Office, we can read the statement:

It is not enough to work solely on single, individual environmental issues ... the capitalist state and its symbols of propaganda must also be targeted... the ELF ideology maintains that it is the very social and political ideology in operation throughout westernized countries that is creating various injustices on this planet and ultimately the destruction of life. That ideology is capitalism and the mindset that allows it to exist (quoted in Ackerman 2003b, 189).

Such proclamations are crucial to my case that we should regard the ELF and its supporting community as a radical reticulation of the wider antiglobalization movement. While the ideological leanings of particular ELF 
adherents may be difficult to ascertain because of their clandestine nature (Joosse 2007), thus far much evidence seems to point in this direction.

Convicted ELF actors frequently display anti-globalist and anarchist tendencies. Craig 'Critter' Marshall, who served a five-and-a-half year sentence for fire-bombing a Chevrolet dealership in Eugene, Oregon, admitted to New York Times reporter Bruce Barcott that growing up, he "held political beliefs that weren't so much pro-environment as anti-authority" (Barcott 2002, 58). In an article entitled, "Attack the System," he professes to have come to the conclusion that "what we need to attack is the totality of the death machine that is industrial society, AKA civilization" $(2006,195)$. Similarly, Jeffrey Luers, who was sentenced to twenty-two year and eight-month years in prison for his participation in the arson, ${ }^{7}$ remarked in an interview with Earth First! Journal that "originally I was radicalized by anti-authoritarian, anarchist beliefs, as well as animal rights," and that his environmental radicalism came only in 1997.8 According to ethnographer Bron Taylor, ELF spokespersons Craig Rosebraugh and Leslie James Pickering "were drawn to the ELF because, as anarchists, if not anarcho-primitivists, they perceived fellow travelers behind the anti-industrial rhetoric of some ELF statements" $(2003,177)$. Thus, it would seem that the change embraced by some in the radical environmental movement, from the relatively mild direct actions of Earth First! to the incendiary tactics of the ELF, was the result of an influx of those who 'greened' their preexisting sympathies towards anarchism and anti-globalization, rather than through an increased radicalization of long-term members.

Perhaps most instructive with regard to the green anarchist ideological orientations of ELF actors are the communiqués that usually follow actions. One communiqué, released after an arson attack on a United States Forest Service research station in Irvine, Pennsylvania, on August 11, 2002, claimed that:

This lesson in "prescribed fire" was a natural, necessary response to the threats posed to life in the Allegheny Forest by proposed timber sales, oil drilling, and greed-driven manipulation of Nature... .

... These agencies continue to ignore and mislead the public, at the bidding of their corporate masters ... the irrevocable acts of extreme violence they perpetrate against the Earth daily are all inexcusable, and will not be tolerated. If they persist in their crimes against life, they will be met with maximum retaliation... . The diverse efforts of this revolutionary force cannot be contained, and will only continue to intensify as we are brought face to face with the oppressor in inevitable, violent confrontation. We will stand up and fight for our lives against this

\footnotetext{
${ }^{7} \mathrm{Hi}$ sentence was later reduced to ten years.

8 Interview available at <www.spiritoffreedom.org.uk/profiles/free/ef.html $>$ accessed October 20, 2008.
} 
iniquitous civilization until its reign of TERROR is forced to an end-by any means necessary (quoted in Best and Nocella 2006a, 413-414).

An arson at Boise Cascade's (a multinational logging company) 8,000 squarefoot northwest headquarters was followed by the ELF communiqué below, which professed a knowledge and outrage at the corporation's international operations:

Boise Cascade has been very naughty. After ravaging the forests of the Pacific Northwest, Boise Cascade now looks toward the virgin forests of Chile. Early Christmas morning, elves left coal in Boise Cascade's stocking. Four buckets of diesel and gas with kitchen timer delay destroyed their regional headquarters in Monmouth, Oregon.

Let this be a lesson to all greedy multinational corporations who don't respect their ecosystems (quoted in Rosebraugh 2004, 94).

Finally, one of the most incendiary of the communiqués was also one of the earliest, released in 1997:

ELF works to speed up the collapse of industry, to scare the rich, and to undermine the foundations of the state. We embrace social and deep ecology as a practical resistance movement... . We take inspiration from Luddites, Levellers, Diggers, the Autonome squatter movement, the ALF, the Zapatistas, and the little people-those mischievous elves of lore... . let's dance as we make ruins of the corporate money system (quoted in Rosebraugh $2004,20)$.

These communiqués display many hallmark themes of the anti-globalization movement-most notably a commitment to fighting neoliberal capitalism and a general disdain for hierarchical authority structures.

Some publications, such as the quarterly, Green Anarchy: An AntiCivilization Journal of Theory and Action, also give signal to the general ideological orientation of the milieu in which the ELF operates. The journal reports on ELF actions worldwide highlight the plight of ELF prisoners, and frequently contains articles by John Zerzan and other anarcho-primitivists who figure heavily in the most revolutionary strains of radical environmentalism (Best and Nocella 2006b, 18). The Spring 2006 issue of Green Anarchy contains sections devoted to "anti-capitalist and anti-state activities," "anarchist resistance," and "ecological resistance" (Anonymous 2006, 40-43, 45, 36, 30).

The theme of worldwide revolution also figures very prominently in the discourses of ELF adherents. Best and Nocella's book, ${ }^{9}$ which contains chapters by ELF prisoners and ELF communiqués, is titled Igniting a Revolution: Voices

${ }^{9}$ It is published by, AK Press, which is "a worker run book publisher and distributor organized around anarchist principles." 
in Defense of the Earth, implying that ELF arsons are meant to serve as catalysts to a wider revolutionary force. In a more aggressive tone, ELF spokesperson Leslie James Pickering writes, "we've gotta prove to the people that we are fighting to win, that revolution is possible, that we can turn this motherfucker upside down and finally break free" $(2006,305)$. Many ELF proponents, when speaking about their revolutionary role, display a penchant for aggrandizing their struggle to near universal proportions. Best and Nocella maintain that their effort is in solidarity with:

Earth liberationists, animal liberationists, Black liberationists, Native Americans, ecofeminists, political prisoners, primitivists, saboteurs, grassroots activists, and militant academics. It reaches out to exploited workers, indigenous peoples, subsistence farmers, tribes pushed to the brink of extinction, guerilla armies, armed insurgents, disenfranchised youth, and to all others who struggle against the advancing juggernaut of global capitalism, neo-fascism, imperialism, militarism, and phony wars on terrorism that front for attacks on dissent and democracy (2006b, 24).

Thus, within the ELF and in its surrounding group of supporters we find many ideological linkages and cross-connections with attitudes prevalent in the wider anti-globalization movement. A focus on the injustices of neoliberal capitalism, a dismissive attitude towards nation-states and electoral politics, claims of solidarity with many other social movements, and the belief that a transnational revolution is in the making are all common themes.

\section{Discussion: Criticisms of the Anti-Globalization Movement and Their Applicability to the ELF}

If we can regard the ELF as one extension, among many, of the larger antiglobalization movement, then we would do well to assess it on those terms. Aside from the obvious neoliberal objections that corporate elites and some state leaders have to the anti-globalization movement, the movement also has endured much criticism from those on the left. These criticisms have taken three main forms.

First, there has been much criticism against some forms of the 'direct action'10 prevalent in the movement, especially the property destruction carried out by the Black Bloc (protesters who traditionally wear black face coverings to foster anonymity and a sense of unity during protests) and other anarchical elements. Because the media unfailingly frames these actions as "senseless violence" and links them to "discourses of terrorism and fear" (Juris 2005,

10 'Direct action' is an umbrella term that includes acts of civil disobedience, such as sitins, as well as acts of sabotage and property destruction. 
423), many feel that these actions work counter to the movement's aims by enabling corporate media and law enforcement to demonize activists as anarchical parasites who seek to take advantage of the free-for-all atmosphere created by mega-protests (Albertani 2002). The media's often sensationalistic gaze means that a few acts of property destruction can taint public perceptions of an entire protest, and accordingly, many of the most vehement arguments against property destruction have been leveled by more moderate, 'reformist' factions of the left (discussed by McNally 2002, 246-247; Rosebraugh 2004, 92). In sum, this first criticism argues that property destruction has had a negative effect on the seriousness with which political leaders and the public take the protests, and has resulted in a further legitimation of police brutality and the militarization of protest management.

On the one hand, the ELF's actions do not occur in conjunction with specific protests, and it cannot, therefore, be accused of acting to sabotage these protests' effectiveness in any immediate way. On the other hand, despite the best efforts of ELF spokespersons, corporate and state interests have been very successful in shaping popular conceptions of the ELF as an "ecoterrorist" organization (Joosse 2012; Vanderheiden 2008). As a result, discourses of ecoterrorism have been normalized to the point where John Lewis, who is an FBI deputy assistant director and top official in charge of domestic terrorism, labeled ecoterrorism-along with animal liberation terrorism-as "the No. 1 domestic terrorism threat"11 in 2005 (quoted in Schuster 2005). Thus, the ELF has unwittingly played a crucial role in furthering the capitalist interest in frame-bridging between the "war on terror" and anti-environmentalism in North America and promulgating the stereotypical vision of greens as antirational, potentially dangerous, 'kooks.' Thus, while the ELF may not be damaging in an immediate way to the mega-protests of the anti-globalization movement, in the wider arena of public discourse in which there is a struggle to make environmental and radical social justice concerns legitimate, the ELF has clearly played a similarly damaging role as the Black Bloc, which often had a 'spoiler' effect on the otherwise-peaceful mega-protests of the antiglobalization movement.

The second criticism comes from environmental activists and theorists who question the effectiveness of the mega-protests themselves as a form of resistance. Naomi Klein has criticized the mega-protest strategy, saying that it tends to attract "meeting-stalkers, [who are intent on] following the trade bureaucrats as if they were the Grateful Dead" (2000, 4 of 6). Similarly, Stainsby (2003) points to a need to move beyond what he somewhat playfully and somewhat derisively refers to as "summit-hopping." The general thrust of these

11 This 'number one' designation had been reserved for right-wing militias that have spawned the likes of bomber Timothy McVeigh and murderous anti-abortionists like Eric Rudolph. 
criticisms is that, while the major gatherings provide a venue for people to profess their idealistic visions for the future and for global change, they provide very little direction or motivation for concrete, local action in the times between these gatherings. What is more, in the aftermath of the 'Battle of Seattle,' the shifting of the 2001 Asian Development Bank meeting from Seattle to Honolulu (Bello 2001) and the siting of the 2002 G8 summit in Kananaskis, Alberta, show that there is nothing to prevent meeting organizers from simply moving meetings to increasingly inaccessible locations in order to avoid uncomfortable confrontations with protestors. Thus, the mega-protests-which are aimed at giving a voice to those who are 'below,' could ironically serve as impetus for a 'Bilderbergization' of meetings-creating more distance between the powerful and the powerless.

In some senses, the method of the ELF would seem to be the perfect antidote to the highly episodic form that the anti-globalization movement has taken thus far. Through the strategy of "leaderless resistance," the ELF encourages ongoing, local action in response to specific environmental problems (Joosse 2007; 2012). By seeking to cause economic damage to corporations with environmentally deleterious practices, the ELF strives to make a practical difference by eliminating the profit motive from environmental destruction. Indeed, as history has shown, and as is discussed above, the impetus for the formation of radical groups like the ELF and, in its time, Earth First!, was the desire to move beyond mere banner-waving in favor of getting real results.

When one looks over the years in which the ELF has been operative, however, the actions have proven to be not only impractical, but counterproductive. Insurance payouts often mean that corporate operations will continue after a brief interruption-at times even on a greater scale after having been given the opportunity to build new facilities (as happened with the Vail ski resort). What is more, the lack of broader organizational cooperation among ELF adherents may foster the NIMBY ("Not in my back yard.") effect, so that even if actions are actually successful in driving corporate operations away from a particular area, the problems associated with them may merely be exported to other areas where, for whatever reason, there is a less bullish environmental activist community. Finally, though ELF adherents intend that their actions will serve to spark a wider revolutionary force "from below," one cannot help but sense that there is something elitist in the way that these small bands of would-be heroes are seeking this catalytic role for themselves. Thus, while (from the perspective of movement adherents) there may be some immediate benefits to the ELF's challenging of corporate operations in some areas, their actions are still very different from the inclusive, continual, local, political involvement that is sorely lacking in the anti-globalization movement generally. This brings us to the last critique of the anti-globalization movement that we will consider here. 
Third and finally, some criticize the anti-globalization movement's near exclusive preoccupation with the transnational political sphere. Anti-globalists often see their protests not "as acting in opposition within a particular state, nor [in] the relation of society and the state, but ... more and more [as] acting to promote a certain kind of political consciousness transnationally that could radiate influence in a variety of directions" (Falk 1993, 47). McNally similarly advocates that we "overcome the horizons of nationalism" $(2002,241)$ and downplays the importance of national, electoral politics though his recommendation of 'the overcoming of passive, representative 'democracy' by activist, direct democracy" (2002, 240). Contrasting this view, Laxer (2003) argues that states remain central actors in the world economy, and that combating the U.S. - the most powerful state in the world-is an essential component to any serious challenge of neoliberal globalism (see also Gindin 2003). In this argument, national contexts are the most effective locus of resistance, because the U.S.'s interests are negotiated and enacted often not directly, but rather through the governments of core state allies that are complicit with neoliberal aims. Thus, discourses of nationalism and systems of electoral politics have the greatest potential for mobilizing citizens to challenge and change their governments' complicity with the economic aims of American-led corporate globalization.

Clearly mobilizing in this regard are grievances that stem from trade disputes between the U.S. and its core allies. The disputes that have occurred between Canada and the U.S. over softwood lumber and steel tariffs in recent years are examples. Additionally, a too-close relationship with the U.S. has the potential to be toxic for the careers of individual national political leaders. Tony Blair, for example, endured much criticism for his government's lock-step following of US foreign policy (Cowell 2006), and during his tenure, it was clear that no self-respecting British citizen wanted to be led by someone who is portrayed as an emasculated "poodle" of George W. Bush (Hoge 2002; Hoge 2003; Stanley 2006; Tyler 2004). Other leaders who have been largely supportive of the US's foreign policy aspirations, such as Stephen Harper in Canada, have had to fend off similar accusations. Thus, keeping the "poodle" perception at bay has been a key impression-management problem for national leadership generally.

Those who argue for nationalistic resistance to US imperialism believe that the grievances of the core nation states that surround the US can have vast implications-if these grievances reach a sufficient pitch. They argue that these nations do in fact have the power (collectively, if not singularly) to jeopardize the taken-for-granted support that the US enjoys and uses to carry out its foreign policy aims (Canada's refusal to support the US's war with Iraq is one example, the rise of Hugo Chavez in Venezuela offers another). This decidedly nationalist strategy fittingly requires political mobilizations within national contexts-a vastly different requirement than that of transnationalists, 
who see the nation-state as an outmoded and therefore ineffectual political sphere of resistance.

As we have seen, the ELF, itself a radical branch of the anti-globalization movement, also has ignored national and international political dynamics, comporting itself primarily to the transnational sphere. In classic Marxian transnational fashion, its adherents seek to "ignite" a worldwide revolution, in which the "elves" rise up to "make ruins of the corporate money system" (quoted in Rosebraugh 2004, 20). They take no advantage of the mobilizing potential of international trade disputes, and they have not sought to capitalize on embarrassing national leaders who are complicit with US hegemony. Thus, the nationalistic criticism of the anti-globalization movement would seem to be similarly applicable to the ELF, for though political channels are often frustrating, giving up on them may be unwise and perilous.

But in the end, debates about the need for national foci may be moot in the case of the ELF. Even when judged on transnational terms, the ELF is open to charges of simple failure. Though ELF actions have been occurring since 1992, thus far they have failed to produce any substantial achievements in the transnational sphere, and have yet to spark even the beginnings of the transnational mass-movement that adherents had envisioned.

\section{Conclusion}

This article has made a case for conceiving the ELF as at least analogous with, if not part of, the larger anti-globalization movement. In the final analysis, it would seem that criticisms directed against the anti-globalization movement also provide an interesting starting point for a critique of the ELF and other advocates of environmentally-motivated large-scale property destruction. These criticisms have maintained that the movement's preoccupation with the transnational sphere and abandonment of national electoral politics is misguided; that direct actions such as property destruction are counterproductive to the wider aims of the movement; and that the tactics employed, whether they be mega-protests or direct action attacks, are too episodic and do very little to encourage practical, inclusive, local, and sustained action in the service of global justice. Thus, whatever benefits the ELF gains from its tactics of property destruction-either in the facilitation of radical identity formation or in the satisfaction of financially damaging their enemies - they do not seem to remedy the problems found in the larger antiglobalization movement that it inhabits.

\section{Literature}

Abbey, E. 1975. The Monkey Wrench Gang. Philadelphia: Lippincot. 
Ackerman, G. A. 2003a. "Beyond Arson? A Threat Assessment of the Earth Liberation Front”. Terrorism and Political Violence 15 (4): 143-170.

—. 2003b. "My Reply to Perlstein and Taylor". Terrorism and Political Violence 15 (4): 183-189.

Albertani, C. 2002. "Paint it Black: Blaco Blocs, Tute Bianche and Zapatistas in the Anti-Globalization Movement”. New Political Science 24 (4): 579595.

Altheide, D. L. 2004. “Consuming Terrorism”. Symbolic Interaction 27 (3): 289308.

Anonymous. 2006. "Ecological Resistance from Around the World". Green Anarchy 22: 30-31.

Baker, Al. 2001. "A Federal Case in Suffolk: Eco-Terrorism or Adolescence in Bloom?". New York Times February 18.

Barcott, B. 2002. "From Tree-Hugger to Terrorist: How Critter Became Part of a Shadowy, Increasingly Violent Radical Environmental Movement". New York Times Magazine April 7: 56-59 \& 81.

Bari, J. 1994. Timber Wars. Monroe, ME: Common Courage Press.

Beck, C. J. 2007. "On the Radical Cusp: Ecoterrorism in the United States, 19982005". Mobilization: An International Journal 12 (2): 161-176.

Bello, W. 2001. "2001: The Year of Global Protest Against Globalization”. Canadian Dimension 35 (2): e-text, no page numbers.

Best, S. \& Nocella II, A. J. (Eds.) 2006a. Igniting a Revolution: Voices in Defense of the Earth. Oakland, CA: AK Press.

- 2006b. "A Fire in the Belly of the Beast: The Emergence of Revolutionary Environmentalism". In Best, S. \& Nocella II, A. J. (Eds.) 2006a. Igniting a Revolution: Voices in Defense of the Earth. Oakland, CA: AK Press: 8-29.

—. 2006c. "Revolutionary Environmentalism: An Emerging New Struggle for Total Liberation". (Paper presented at the Third Annual Conference on Education, Labor and Emancipation held at El Paso, Texas and Ciudad Juarez, Chihuahua, Mexico, September 28-October 1). Available from: http://greentheoryandpraxis.csufresno.edu/articles/nocella.doc [Accessed March 28, 2007].

Bookchin, M. \& Foreman, D. 1991. Defending the Earth: A Dialogue Between Murray Bookchin and Dave Foreman. Boston: South End Press.

Broad, R. \& Heckscher, Z. 2003. "Before Seattle: The Historical Roots of the Current Movement Against Corporate-Led Globalization". Third World Quarterly 24 (4): 713-728.

Brooke, J. 1998. "Group Claims Responsibility For Blazes at Vail Resort”. New York Times October 22.

Brown, Ch. S. 2007. "Beyond Intrinsic Value: Undermining the Justification of Ecoterrorism." American Journal of Economics and Sociology 66 (1): 113-125. 
Cowell, A. 2006. "Critics Say Mideast Crisis hitches Blair Closer to Bush". New York Times July 28.

Della Porta, D. 2005. "Democracy in Movement: Participation and Deliberation in the Movement for a 'Globalization from Below'”. Rassegna Italiana di Sociologia 46 (2): 307-341.

- 2006. Globalization from Below: Transnational Activists and Protest Networks. Minneapolis: University of Minnesota Press.

Falk, R. 1993. "The Making of Global Citizenship". In Brecher, J., Brown Childs, J., \& Cutler, J. (Eds.), Global Visions: Beyond the New World Order. Boston: South End Press.

Foreman, D. 1991. Confessions of an Eco-warrior. New York, N.Y.: Harmony Books.

Foreman, D. \& Haywood, B. (Eds.). 1993. Ecodefense: A Field Guide to Monkeywrenching, $3^{\text {rd }}$ ed. Chico, CA: Abbzug Press.

French, M. 2002. "Post-September 11 realities". The Manitoban January 23. Retrieved from: http://www.themanitoban.com/20012002/0123/features index.shtml [Accessed November 20, 2006].

Gindin, S. 2003. "Sovereignty and Empire". Canadian Dimension 37.

Gitlin, T. 2012. Occupy Nation: The Roots, Spirit, and Promise of Occupy Wall Street. Harper-Collins: New York.

Habermas, J. 1981. "New Social Movements". Telos 49: 33-37.

Harvie, D., Milburn, K., Trott, B. \& Watts, D. (Eds.) 2005. Shut Them Down! The G8, Gleneagles 2005, and the Movement of Movements. West Yorkshire, UK; Brooklyn, NY: Autonomedia.

Hoge, W. 2002. “Tony Blair's Role: Statesman, or Poodle”. New York Times September 26.

—. 2003. "Critics Mobilize and London Police Brace for Bush's Visit". New York Times November 6.

Johnston, J. 2004. “Who Cares About the Commons?”. Capitalism, Nature, and Socialism 14 (4): 1-41.

Joosse, P. 2007. "Leaderless Resistance and Ideological Inclusion: the Case of the Earth Liberation Front". Terrorism and Political Violence 19 (3): 351368.

—. 2012. "Elves, Environmentalism, and 'Eco-Terror': Leaderless Resistance and Media Coverage of the Earth Liberation Front". Crime, Media, Culture 8 (1): 75-93.

Juris, J. S. 2005. "Violence Performed and Imagined: Militant Action, the Black Bloc and the Mass Media in Genoa". Critique of Anthropology 25 (4): 413-432.

Klein, N. 2000. "The Vision Thing”. The Nation July 10. Retrieved from: http://www.thenation.com/doc/20000710/klein [Accessed 20 November, 2006]. 
Laxer, G. 2003. "Radical Transformative Nationalisms Confront the US Empire”. Current Sociology 51 (2): 133-152.

Leader, S. H. \& Probst, P. 2003. "The Earth Liberation Front and Environmental Terrorism". Terrorism and Political Violence 15 (4): 37-58.

Lee, M. F. 1995. Earth First!: Environmental Apocalypse. Syracuse, NY: Syracuse University Press.

Luers, J. 'Free.' 2006. "From Protest to Resistance”. In Best, S. \& Nocella II, A. J. (Eds.), 2006a. Igniting a Revolution: Voices in Defense of the Earth. Oakland, CA: AK Press: 211-223.

Manes, Ch. 1990. Green Rage: Radical Environmentalism and the Unmaking of a Civilization. Boston, Toronto, and London: Little, Brown and Company.

Marshall, C. 'Critter.' 2006. "Attack the System". In Best, S. \& Nocella II, A. J. (Eds.), 2006a. Igniting a Revolution: Voices in Defense of the Earth. Oakland, CA: AK Press: 195-197.

Martin, W. 1982. "Waiting for the End: Growing Interest in Apocalyptic Prophecy". Atlantic Monthly 249: 35.

McNally, D. 2002. Another World is Possible: Globalization and Anti-capitalism. Winnipeg: Arbeiter Ring Publishing.

Molland, N. 2006. "The Spark that Ignited the Flame". In Best, S. \& Nocella II, A. J. (Eds.), 2006a. Igniting a Revolution: Voices in Defense of the Earth. Oakland, CA: AK Press: 47-58.

Naess, A. 1973. "The Shallow and the Deep. Long-Range Ecology Movements: A Summary". Inquiry 16: 95-100.

NPR. 2012. "Transcript of the Second Presidential Debate". Retrieved from: http://www.npr.org/2012/10/16/163050988/transcript-obamaromney-2nd-presidential-debate [Accessed November 5, 2012].

Peeples, J. 2005. "Aggressive Mimicry: The Rhetoric of Wise Use and the Environmental Movement". In The Environmental Communication Yearbook Vol. 2. New Jersey: Taylor and Francis.

Pickering, L. J. 2006. “People Ain't Feeling this Bullshit”. In Best, S. \& Nocella II, A. J. (Eds.), 2006a. Igniting a Revolution: Voices in Defense of the Earth. Oakland, CA: AK Press: 301-305.

Plows, A., Wall, D. \& Doherty, B. 2004. "Covert Repertoires: Ecotage in the UK". Social Movement Studies 3 (2): 199-219.

Ramonet, I. 2001. "The Promise of Porto Alegre". Le Monde Diplomatique January. Retrieved from: http://mondediplo.com/2001/01/01portoalegre [Accessed November $20,2006]$.

Rosebraugh, C. 2004. Burning Rage of a Dying Planet: Speaking for the Earth Liberation Front. New York, NY: Lantern Books.

Rothman, H. K. 2000. Saving the Planet: The American Response to the Environment in the Twentieth Century. Chicago: The American Ways Series. 
Schuster, H. 2005. “Domestic Terror: Who's the Most Dangerous? Eco-terrorists are now above ultra-right extremists on the FBI charts". CNN.com August 24. Retrieved from: http://www.cnn.com/2005/US/08/24/schuster.column/index.html [Accessed November 21, 2006].

Smith, R. A. 2007. "The Eco-suicidal Economics of Adam Smith". Capitalism, Nature, Socialism 18 (2): 22-43.

Stanley, A. 2006. "Covering a Friend's Back: Leaders Reverse the Roles". New York Times May 26.

Soron, D. \& Laxer, G. (Eds.) 2006. Not For Sale: Decommodifying Public Life. Toronto: Broadview Press.

Stainsby, M. 2003. "Beyond Summit-Hopping? G8's retreat to Kananaskis and the Way Ahead". Socialism and Democracy 17 (2): 191-215.

Starr, A. 2006. “.... (Excepting Barricades Erected to Prevent Us from Peacefully Assembling)': So-called 'Violence' in the Alterglobalization Movement". Social Movement Studies 5 (1): 61-81.

Taylor, B. 1994. "Earth First!'s Religious Radicalism”. In Key Chapple, Ch. (Ed), Ecological Prospects: Scientific, Religious, and Aesthetic Perspectives, Albany: State University of New York Press: 185-209.

—. 1998. "Religion, Violence and Environmentalism: From Earth First! to the Unabomber, to Earth Liberation Front". Terrorism and Political Violence $10(4): 1-42$.

—. 2003. "Threat Assessments and Radical Environmentalism". Terrorism and Political Violence 15 (4): 173-182.

—. 2005. "Earth First! And the Earth Liberation Front". In Taylor, B. (Ed.), Encyclopedia of Religion and Nature. London and New York: Thoemmes Continuum: 518-524.

Tyler, P. E. 2004. "Blair's Prize is President's Commitment". New York Times November 13.

Vanderheiden, S. 2005. "Eco-Terrorism or Justified Resistance? Radical Environmentalism and the 'War on Terror'”. Politics and Society 33 (3): 425-447.

-. 2008. "Radical Environmentalism in an Age of Antiterrorism". Environmental Politics 17 (2): 299-318.

Vos, J. 2009. "Actions Speak Louder than Words: Greenwashing in Corporate America". Notre Dame Journal of Law, Ethics, and Public Policy 23: 673697.

Vozzella, L. 2012. "Environmentalists Blast 'Pro-Coal' Obama Ad." The Washington Post November 10.

Whitehouse press release. 2001. "President Outlines War Effort”. October 17. Retrieved from: www.whitehouse.gov/news/releases/2001/10/20011017-15.html [Accessed March 28, 2007]. 
Paul Joosse (University of Alberta)

\title{
Antiglobalization and Radical Environmentalism: An Exchange on Ethical Grounds
}

\begin{abstract}
Since 1992, clandestine radical environmentalist cells, calling themselves the Earth Liberation Front (ELF), have carried out arson attacks in an effort to punish corporations for environmentally deleterious practices. I examine the radical environmental movement and find that its recent rise to prominence and notoriety is part and parcel of the larger development of the more general anti-globalization/anti-capitalist movement. Specifically, I examine how, despite its libertarian conservative origins, the ideology of Earth First! changed after an influx of new members with anti-state, anarchist sympathies. Finally, I assess the applicability of three major criticisms of "globalization from below" to the case of the ELF, namely: a) that its preoccupation with the transnational sphere and abandonment of electoral politics is misguided, b) that direct actions such as property destruction are counterproductive to the wider aims of the movement, and, c) that its strategies of contention are too episodic, and do very little to encourage practical, inclusive, local, and sustained action in the service of global justice.
\end{abstract}

Key words: Radical environmentalism, ecoterrorism, anti-globalization, social movements, environmental ethics, leaderless resistance, Earth Liberation Front

Ethics in Progress (ISSN 2084-9257). Vol. 5 (2014). No. 1. pp. 33-51.

doi:10.14746/eip.2014.1.2 